\title{
KOSMETIKA ONKOLOGIKOA: kimioterapiak eta erradioterapiak larruazalean eragindako efektu desira- gaitzak eta horiek tratatzeko konposatu naturaletan oinarritutako formulazio berriak (ONCOLOGIC COSMETICS: undesirable effects caused by chemotherapy and radiotherapy in the skin and new formulations to treat these disorders)
}

\author{
Miren Izaguirre, Edorta Santos-Vizcaíno ${ }^{1,2}$, Aiala Salvador ${ }^{1,2}$, \\ Amaia Esquisabel ${ }^{1,2}$, José Luis Pedraz ${ }^{1,2}$, Rosa María Hernández ${ }^{1,2}$, \\ Manoli Igartua ${ }^{1,2 *}$ \\ ${ }^{1}$ NanoBioCel Taldea, Teknologia Farmazeutikoko Laborategia, Euskal Herriko \\ Unibertsitatea (UPV/EHU), 01006, Gasteiz \\ ${ }^{2}$ Ikerkuntza BiomedikokoZentro Sarea Bio-ingeniaritza, Biomaterial \\ eta Nano-medikuntzan (CIBER-BBN). Gasteiz \\ *manoli.igartua@ehu.eus
}

DOI: $10.1387 /$ ekaia.17837

Jasoa: 2017-05-11

Onartua: 2017-09-18

Laburpena: Sarritan, tratamendu onkologikoek pazientearen bizi-kalitatea baldintzatu dezaketen efektu desiragaitzak sortzen dituzte, minbizi-zelulak kaltetzeaz gain, bestelako ehun osasuntsuak suntsitzen baitituzte. Lan honetan tratamendu onkologikoen ondorioz larruazalean sortutako gaitzak aztertuko dira (hala nola pruritoa, ezkatatzea edota ultzerazioa kasu larrienetan) eta baita arazo horiei aurre egiteko formulatu diren produktu berrien konposizioa ere. Orain arte erabili diren kortikoide, antihistaminiko edo lidokainadun kremak alde batera uzteko helburuarekin, laborategi dermokosmetikoek paziente onkologikoen larruazala tratatzeko bestelako produktu-lerroak merkaturatu dituzte, horien bizi-kalitatea hobetu eta eragin desiragaitz berantiarren agerpena oztopatzeko asmoz. Antzinatik erabili izan diren landare-estraktuez baliatuz, larruazalaren erreparaketa-prozesua bultzatzea helburu duten formulazioak diseinatu dituzte, Maria D'uol edota OnCosmetics laborategien produktu-lerroak bezala. Beste kasu batzuetan, landare-jatorriko konposatuez gain, bestelako molekula aktiboak erabili di- 
Miren Izaguirre, Edorta Santos-Vizcaíno, Aiala Salvador, Amaia Esquisabel, José Luis Pedraz, Rosa María Hernández, Manoli Igartua

tuzte; hala nola, BEACON Biomedicine laborategien kasuan, hazkuntza-faktoreak eta Tectum 11 izeneko proteina-konplexuak erabiltzen dituzte, edota IFC laborategian, Cryptomphalus aspersa barraskilotik lortutako jariakinaz baliatzen dira tratamendu onkologikoen ondorioz sortutako larruazaleko gaitzak erreparatzeko.

Hitz gakoak: minbizia; larruazal-asaldurak; kimioterapia; erradioterapia; produktu naturalak.

Abstract: Often, cancer treatments create undesirable effects that may compromise the patient's quality of life, given that besides killing cancer cells, they also destroy other healthy tissues. The present work discusses the skin diseases caused by cancer treatments, such as pruritus, flaking and/or ulceration in the most severe cases, as well as new products that are formulated to address these issues. With the aim of leaving aside the so far used corticoids, anti-histaminic drugs or lidocaine creams, dermo-cosmetic laboratories are now releasing alternative product lines for the skin treatment of patients with oncologic disorders. This is intended to improve their quality of life, hindering the unwanted late onset effects. By using plant extracts that have been used since ancient times, different formulations have been designed to promote the skin regeneration process. Product lines from laboratories such as Maria D'uol and OnCosmetics represent good examples of this. In other cases, besides plant origin compounds, other active molecules are also included. This is the case of BEACON Biomedicine laboratories, working with growth factors and a complex protein called Tectum 1; or IFC, where the fluids obtained from Cryptomphalus aspersa snails are used for the treatment of skin disorders caused by cancer.

Keywords: cancer; skin damages; chemotherapy; radiotherapy; natural products.

\section{SARRERA}

Minbiziaz hitz egiten dugunean, elkarrekin erlazionaturik dauden gaitzen multzoaz ari gara. Kasu guztietan, gorputzeko zelula batzuek zatiketa zelularra kontrolatzeko gaitasuna galtzen dute, zelulak behin eta berriz zatituz. Horiek alboko ehunak inbadi ditzakete eta baita urrutiko ehunak ere. Inbasio horri metastasia deritzo.

Minbizia gorputzeko edozein lekutan sor daiteke, gaixotasun horren etiologia zelula baten aldaketa baita. Normalean, gorputzeko zelulak zaharkitu edo kaltetzen direnean, horiek apoptosi prozesuan sartu eta zelula berriengatik ordezkatzen dira. Baina minbizian prozesu honek kontrola galtzen du: zelula zahar edo kaltetuek bizirauten dute eta zelula berriak sortzen dira gorputzak beharrezkoak ez dituenean, «neoplasia» edo «tumorea» deritzon zelula-masak sortuz. Horiek alboko ehunak suntsitu eta ehun normalak ordezkatzen dituzte. Zatiketa zelularraren kontrolaren galera gertatzen da zelula baten DNA edota mekanismo erregulatzaileak kaltetuak izaten direnean, etengabeko zelula berriak sortzen dira $[1,2]$. 
KOSMETIKA ONKOLOGIKOA: kimioterapiak eta erradioterapiak larruazalean eragindako efektu desira-gaitzak eta horiek tratatzeko konposatu naturaletan oinarritutako formulazio berriak

Tratamenduari dagokionez, gaur egun kasu gehienetan hiru printzipiotan oinarrituta egoten da: ebakuntza, kimioterapia eta erradioterapia. Tratamendu onkologikoen helburua minbizi-zelulak deuseztatzea da, erradiazio, farmako zitotoxiko edo ebakuntzaren bitartez [3].

Tratamendu horiek efektu desiragaitzak sor ditzakete. Izan ere, tratamendu onkologikoek minbizi-zelulez aparte, zelula normalak ere eliminatzen dituzte. Ehun osasuntsuen suntsiketaren ondorioz, maizago agertzen diren efektu desiragaitzak anemia, apetitu-galera, odol-jarioak, hematomak, beherakoak, edemak, nekea, ile-galera, infekzioak, gorakoak edota larruazalaren asaldurak izaten dira, besteak beste [4]. Azken horien erreparaketa-prozesua azkartzea eta hobetzea helburu duten eta merkaturatu berri diren konposatu naturaletan oinarritutako formulazioak izango dira lan honen aztergai.

\section{LARRUAZALAREN EGITURA ETA BIRSORKUNTZA PROZESUA}

\subsection{Larruazalaren egitura}

Larruazalaren oinarrizko egitura bi geruzaz osatuta dago: epidermisa eta dermisa.

Kanporago aurkitzen dugun geruza epidermisa da. Geruza horretan aurkitzen ditugun zelulak keratinozito, melanozito, immunitate funtzioa duten Lagerhans-en zelulak eta Merkel zelulak dira, nerbio-bukaerekin kontaktu zuzena dituzten zelulak eta ukimenaz arduratzen direnak, hain zuzen ere. Keratinozitoak bata bestearen gainean kokatzen diren zelula-geruzatan antolatzen dira, substantzia gehienentzat iragazgaitza den hesia osatuz. Horiek keratina deritzon proteina jariatzen dute, geruzari gogortasuna emango diona. Beren funtzio garrantzitsuenetarikoa hidratazioa mantentzea da. Era berean, epidermisa hainbat azpi-geruzatan antolatuta dago: geruza basala (stratum basale), arantzatsua (stratum spinosum), pikortsua (stratum granulosum) eta estratu korneoa (stratum corneum). Larruazala lodiagoa den zonaldeetan, hala nola oin-zola edo esku-azpietan, epidermisak geruza gehigarri bat du: estratu edo geruza gardena (stratum lucidum). Geruza hori estratu korneo eta pikortsuaren artean kokatzen da (1. irudia).

Aipatzekoa da geruza basala edo germinatiboa diferentziatu gabe eta kapazitate mitotiko handia duten zelula lerroez osaturik dagoela. Garrantzi handiko geruza da, izan ere, larruazalaren erregenerazio gaitasunaren arduraduna da. Zelula horiek izango dira keratinozito bilakatuko direnak desberdintzen doazen heinean. Geruza horretan, melanina ekoizteaz arduratzen diren zelulak ere aurkituko ditugu: melanozitoak. Pigmentu hori azalaren koloreaz eta eguzki-izpiek izan ditzaketen efektu desiragaitzeta- 
Miren Izaguirre, Edorta Santos-Vizcaíno, Aiala Salvador, Amaia Esquisabel, José Luis Pedraz, Rosa María Hernández, Manoli Igartua

tik babesteaz arduratzen da. Geruza horretan aurkitzen ditugun zelulak dira tratamendu onkologikoaren eraginez kalte nagusia jasoko dutenak.

Geruza arantzatsua geruza basalean sortzen diren keratinozitoez osatutako geruza lodia da. Horiek goranzko bidea egingo dute geruza basaletik zelula berriak sortzen diren heinean.

Geruza bikortsua zelula lauez osatutako geruza da. Zelula horien zitoplasman keratohialinazko pikorrak aurkitzen dira, barruko geruzak lesioetatik eta inbasio mikrobiarretatik babesteko lagungarriak direnak.

Estratu korneoa korneozitoak deritzon laututako zelulez osatuta dago; zelula horiek bata bestearen gainean kokatzen dira eta haien artean loturik mantentzen dira bertan aurkitzen dugun barrera lipidikoari esker, egitura zurrun bat osatuz. Korneozitoek nukleo eta organulu zitoplasmatikoak galdu dituzte eta, batez ere, keratinazko filamentuz eraturik daude. Geruza hori 15-20 zelula-geruzaz eraturik dago, azkena ezkatatzez galtzen dena eta geruza basaletik sortzen diren zelula berriez ordezkatuz doana da.

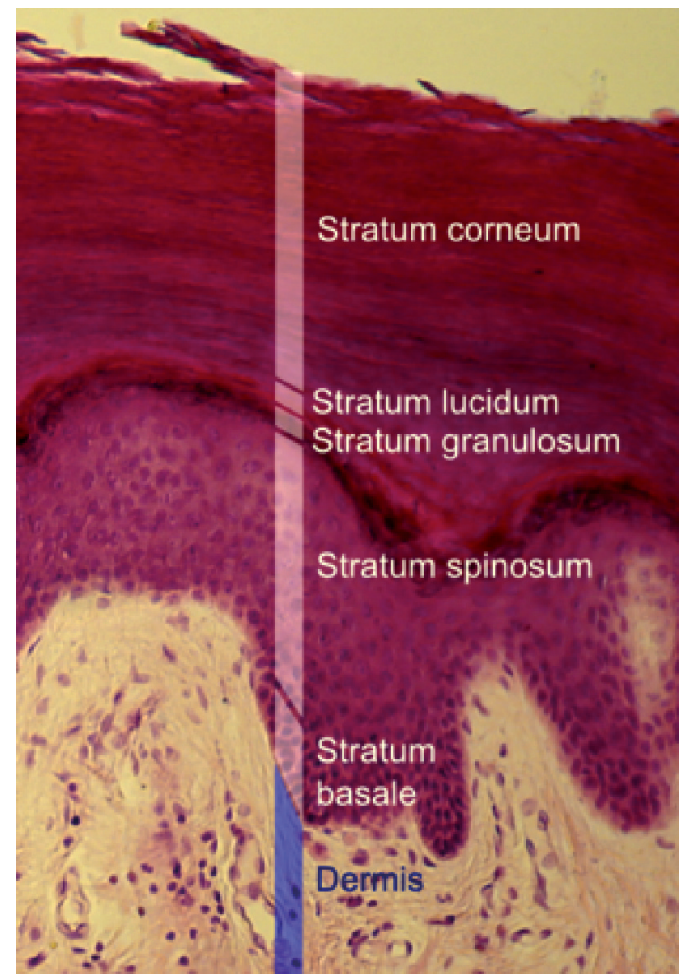

1. irudia. Epidermisaren egitura. Bertan bost azpi-geruza desberdindu daitezke: geruza basala, arantzatsua, pikortsua, geruza gardena eta estratu korneoa. Baimenarekin erreproduzitua [5]. 
KOSMETIKA ONKOLOGIKOA: kimioterapiak eta erradioterapiak larruazalean eragindako efektu desira-gaitzak eta horiek tratatzeko konposatu naturaletan oinarritutako formulazio berriak

Dermisari dagokionez, azalaren parterik handiena da eta organoaren benetako euskarria da. Gainera, epidermisa ez bezala, dermisa baskularizatuta dago, epidermisaren nutrizio-iturria da.

Larruazalaren mintz horretan ez dugu zelula-geruzarik aurkituko, baizik eta «oinarrizko substantzia» deritzon osagai likatsuaz inguraturik dagoen zuntzen sistema konplexua. «Oinarrizko substantziak» oso trinkoturik ez dauden zuntzen proportzio handia dauka, batez ere kolageno- (\% 75), elastina- eta erretikulina-zuntzak. Dermiseko zelula aipagarrienak fibroblastoak dira, zuntzen sintesiaz arduratzen direnak, eta baita sistema immunearen zelulak ere (linfozitoak, makrofagoak, eosinofiloak eta mastozitoak).

Dermisean, gainera, hainbat larruazal-eranskin aurkitzen ditugu, esaterako, ile-folikuluak, gantz-guruinak eta izerdi-guruinak [5].

\subsection{Larruazalaren birsorkuntza-prozesua eta bere garrantzia}

Ugaztunen epidermisaren birsorkuntzaren arduradunak geruza basalean aurkitzen ditugun desberdindu gabeko zelulak dira. Horiek keratinozito bilakatzen dira eta goranzko bidea hartzen dute goiko geruzak eratuz. Estratu korneora heltzen doazen neurrian, keratinozitoak kornifikatzen dira, korneozito bilakatuz eta ingurunearekin kontaktu zuzena duen geruza eratuz.

Errepitelizazio-prozesuan ere dermisaren birsorkuntzak berebiziko garrantzia du. Dermisa berriztatzen da geruza horretan aurkitzen ditugun fibroblastoen migrazioari eta proliferazioari esker. Fibroblasto mugikorrak fibrozitotan diferentziatzen dira, bata bestearekin elongazioz elkartuta daude, egitura tridimentsional bat eratuz. Fibroblastoek kolageno, elastina eta proteoglikano aitzindariak sintetizatu eta askatzen dituzte «oinarrizko substantzia» eraberritzeko. Higadura- eta ordezkapen-prozesu etengabe horrek 30 egunetik behin epidermisaren erabateko eraberritzea dakar, zatiketa zelularra gertatzen den mementotik larruazalaren gainazaletik askatzen den arte [6].

Larruazalaren birsorkuntza egokiak berebiziko garrantzia du pazientearen bizi-kalitatean. Izan ere, larruazalak eguzki-erradiaziotik babesten gaitu, inbasio patogenoak eta barneko ur-lurrunketa saihesten ditu eta, batez ere, gure barneko organoak babesten ditu. Errepitelizazioaren edozein akatsek babes funtzioaren galera ekar dezake eta, hortaz, organoen babesaren galera, deshidratazioa, infekzioak eta kasu larrienetan baita heriotza ere.

Gainera, ugaztunen zaurien osaketan orbaina sor daiteke eta horrek larruazalean aurkitzen ditugun apendizeen galera ekartzen du, hala nola ilefolikulu, azazkal edota izerdi-guruinen galera. Horiek funtzio garrantzitsuak betetzen dituzte gure organismoan, esaterako, termorregulazio eta funtzio sentsorialaz arduratzen dira, besteak beste. 
Miren Izaguirre, Edorta Santos-Vizcaíno, Aiala Salvador, Amaia Esquisabel, José Luis Pedraz, Rosa María Hernández, Manoli Igartua

Tratamendu onkologikoek eratzen dituzten lesio edota erreduren ondorioz sortutako orbainek larruazalaren itxura-aldaketan eragin nabaria dute, ondorio kosmetiko eta psikologiko handiak izan ditzaketenak, gizabanakoaren bizi-kalitatearen murrizketa eraginez [7].

\section{TRATAMENDU ONKOLOGIKOAREN EFEKTU DESIRAGAITZAK LARRUAZALEAN}

Larruazala gure gorputzeko organorik garrantzitsuenetariko bat da, ez bakarrik zabalena delako, baizik eta betetzen dituen funtzioen garrantziagatik.

Kanpoko munduaren eta gure barnekoaren arteko bitartekaria da eta kanpo-erasoen aurkako lehenengo babes-hesia. Larruazalak gorputzeko tenperatura kontrolatzen du eta gure organismoaren hidratazio eta konposizio egokiaz arduratzen da. Metabolismoan ere parte hartzen du D3 bitaminaren sintesian paper garrantzitsua jokatuz, eta hormona anitzen itu da, hormona sexualen kasuan adibidez, horien metabolismo periferikoan parte hartuz. Gainera, gizabanako bakoitzari usain, ukimen eta aspektu berezia ematen dioten guruinak aurki ditzakegu. Interrelazio-funtzioetan ere giltzarria da: kanpo-ingurunetik sentsazio eta estimuluak hautematen ditugu, eta eguneroko bizitzan gure buruaren aurkezpen «txartela» da.

\subsection{Ebakuntza kirurgikoa}

Tumorearen eliminazio kirurgikoa minbiziaren kontrako funtsezko tratamenduaren oinarri izaten jarraitzen du. Ebakuntza kirurgikoa burutu den larruazalaren zonaldean orbain bat geratzen da [8]. Ebakuntzaren ondoren, pazienteak ebakuntza burutu den zonaldean hainbat eragozpen nabari ahal ditu, esaterako, larruazalaren gorritasuna, hematomak, odol-ateratzea, azalaren ezkatatzea, hantura, zornea, beroa edota lama orbainaren zonaldean, mina eta sentikortasuna [9].

\subsection{Erradioterapiak eragindako efektu desiragaitzak}

Erradioterapian (RT) erradiazio ionizatzaileak erabiltzen dira minbizia tratatzeko. Tratamendu luzea izaten da normalean, hainbat astetako iraupenekoa, non pazienteak astero 5 egunetan erradiazio-saioak jasotzen dituen.

Erradiazio horiek gorputzeko ehunekin erreakzionatzen dute zatiketa-fasean dauden zelulen DNA suntsituz, minbizi-zelulen kasuan bezala. Neoplasia kokaturik dagoen gorputzeko atala erradioterapiaz tratatzeko, erradiazio ionizatzaileak larruazala zeharkatu beharko du eta, horren ondorioz, geruza basala eratzen duten diferentziatu gabeko zelulak deusez- 
KOSMETIKA ONKOLOGIKOA: kimioterapiak eta erradioterapiak larruazalean eragindako efektu desira-gaitzak eta horiek tratatzeko konposatu naturaletan oinarritutako formulazio berriak

tatuko dira. Hori gertatzean, goiko geruzetako zelulak kornifikatu eta askatuko dira. Egoera normal batean, larruazalaren erregenerazio-gaitasun handiari esker, kanpoko zelulak suntsitzen direnean, geruza basaletik sortutako beste zelula berriek ordezkatuko dituzte. Baina, kasu horretan, etengabeko erradiazio-saioek kanpoko geruzen berrikuntza oztopatuko dute zelula basalen kopuru murrizpenagatik (2. irudia). Gainera, alterazio horri aurre egiteko, hanturazko prozesua martxan jartzen da histaminaren eta serotoninaren askapenarekin, zelula estra-kapilarren kaltea eta basodilatazioa eraginez.

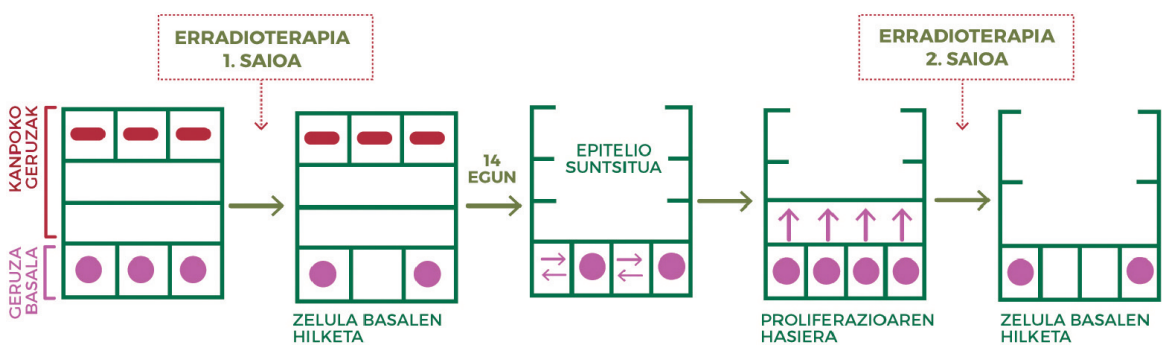

2. irudia. Erradiazioak larruazalaren zeluletan eragiten duen kaltearen ekintzamekanismoa.

Erradiazioak eragindako larruazalaren toxizitateari erradio-dermitisa esaten zaio eta RT jasotzen duten pazienteen \% 95ak pairatzen du. RT tratamendu lokala da eta bere efektuak aplikazio-lekuan bakarrik emango dira.

Erradio-dermitis akutuak tratamenduaren lehenengo eta laugarren astetan zehar ematen diren berehalako erreakzioak dira. Horien artean daude eritema eta edema dermiseko kapilarren dilatazioagatik, pruritoahista minaren askapenagatik eta kanpo-geruzak galtzean ematen den deshidratazioagatik, ile-galtzea ile-folikuluaren galeragatik, ezkatatzea, hiperpigmentazioa melaninaren migrazioagatik kanpoko geruzetara, eta ultzerazioa eta nekrosia kasu larrienetan, berriztatzea ezinezkoa denean eta infekzioen agerpena gertatzen denean [10-12].

Erradio-dermitis kronikoa edo atzeratua tratamendua amaitu eta hainbat hilabetetara edota urtetara agertzen diren gaitzak dira. Horiek gertatzen dira larruazalean eman den erradiazioen pilaketarengatik. Horren ondorio dira kalte hauek: zelula epitelialen atrofia, telangiektasia epidermisaren argaltze eta dermiseko basodilatazioagatik, fibrosia eta, muturreko kasuetan, nekrosia; izan ere, larruazalaren tolerantzia gainditzen denean, geruza basalaren zelula guztiak deusezta daitezke ultzera erradio-nekrosikoa agertuz. 
Miren Izaguirre, Edorta Santos-Vizcaíno, Aiala Salvador, Amaia Esquisabel, José Luis Pedraz, Rosa María Hernández, Manoli Igartua

\subsection{Kimioterapiak eragindako efektu desiragaitzak}

Kimioterapian (QT) farmako zitotoxikoak erabiltzen dira minbizi-zelulak hiltzeko. Astetako iraupena duen tratamendua da, hainbat saiotan gauzatzen dena, eta bertan zitotoxikoak zain-barnetik edo aho-bidetik administratzen dira. Odol-hodietatik neoplasia dagoen tokira arte garraiatzen dira eta minbizi-zelulak deuseztatzen dituzte. RTn gertatzen den bezala, ehun osasuntsuak ere kaltetuak izango dira. Baina, kasu horretan, efektu desiragaitzak ez dira bakarrik aplikazio-puntuan ematen, baizik eta gorputz osoan zehar, farmako zitotoxikoak organismotik garraiatzen baitira. Tokiko nekrolisi epidermikoa injekzio-puntuan, nekrolisi epidermiko orokorra, oin-zolako eta esku-azpiko eritema eta edema [13], erupzio akneiformeak, alopezia eta hiperpigmentazioa dira behatutako hainbat asaldura, besteak beste $[14,15]$.

\section{ORAIN ARTE ERABILITAKO FORMULAZIOAK}

Gaur egun, tratamendu onkologikoaren ondorioz sortutako larruazalaren efektu desira-gaitzak tratatzeko formulazioek asaldurak sintomatikoki tratatzen dituzte, baina ez dute ehun kaltetua erreparatzen ezta erregenerazio-prozesua arintzen ere. Horiek administrazio topikoa duten gel, krema, pomada edo lozioak izaten dira, azkura, eritema, edema edo larruazalaren lehortasuna tratatzeko erabiltzen direnak.

- Hezegarri eta emolienteak: larruazalak duen ura ez galtzeko topikoki administratu den zonaldearen gainean barrera moduko bat eratzen dute eta, era berean, galdutako ura gehitzen diote. Horietatik erabilienak ureadun kremak izaten dira, Ureadin $\mathrm{RX}^{\circledR}$, adibidez [16].

- Antihistaminikoak: histaminaren askapena blokeatzen dute hanturazko erantzuna aktibatzean, azkuraren eta edemaren sintomak murriztuz. Difenhidramina topikoa $\left(\right.$ Caladryl $\left.{ }^{\circledR}\right)$ edo sistemikoa (Benadryl ${ }^{\circledR}$ ) horien adibideak dira.

- Anestesikoak: anestesiko topikoek, lidokainadun kremak adibidez, min-sentsazioa murrizten dute aplikatutako larruazalaren eremuan.

- Kortikoideak: hodi-uzkurtzaile indartsuak dira, iragazkortasun baskularra eta leukozitoen migrazioa inhibituz. Horren adibide bat \% 1eko hidrokortisona krema da, narritadura eta azkura murrizten dituena.

- Antiseptikoak: larruazalaren osotasuna galtzean, mikroorganismoen inbasioa faboratzen da. Beraz, antiseptikoak topikoki eta, kasu batzuetan, baita sistemikoki ere erabiltzea agintzen da, hala nola \% 5 klorhexidina soluzio topikoekin egindako garbiketak $[12,17]$. 
KOSMETIKA ONKOLOGIKOA: kimioterapiak eta erradioterapiak larruazalean eragindako efektu desira-gaitzak eta horiek tratatzeko konposatu naturaletan oinarritutako formulazio berriak

\section{KONPOSATU NATURALAK}

Tratamendu onkologikoaren ondorioz larruazalean sortutako efektu desiragaitzak tratatzeko garatu diren formulazio berrien joera aspaldidanik erabiltzen diren landare-jatorriko produktuen propietateaz baliatzea da. Landare-estraktuek badituzte biologikoki aktiboak diren konposatu kimikoak eta laborategiek, horiek konbinatuta, paziente onkologikoen larruazala tratatzeko hainbat produktu formulatu dituzte, sintoma nagusiak arintzea helburu izango dutenak.

\subsection{Hidratatzaile naturalak}

Landare-jatorriko hidratatzaile naturalak fitozeramida edo gantz-azido esentzialetan (AGE) aberatsak dira. Estratu korneoa larruazalaren hidratazio maila bermatzeaz arduratzen den geruza da eta korneozitoak bata besteari loturik mantentzea funtzio duten konposatuak barrera lipidikoaren osagaiak dira, zeramidak eta bestelako lipidoak, hain zuzen ere. Zeramidek barnealdetik kanpo-ingurunera dagoen ur-transpirazioa kontrolatzen dute eta korneozitoek barnealdean dituzten Faktore Hidratatzaile Naturalak (NMF edo Natural Moisturizing Factor) babesten dituzte larruazaleko hidratazioa bermatuz. Konposatu horien edozein alteraziok barrera horren egitura eralda dezake, ur-trukea aldaraziz. Egoera hori tratamendu onkologikoen ondorioz gertatzen da: barrera lipidikoaren osotasuna galtzen da, urgalera faboratuz (3. irudia). Fitozeramiden erabileraren helburua galdutako

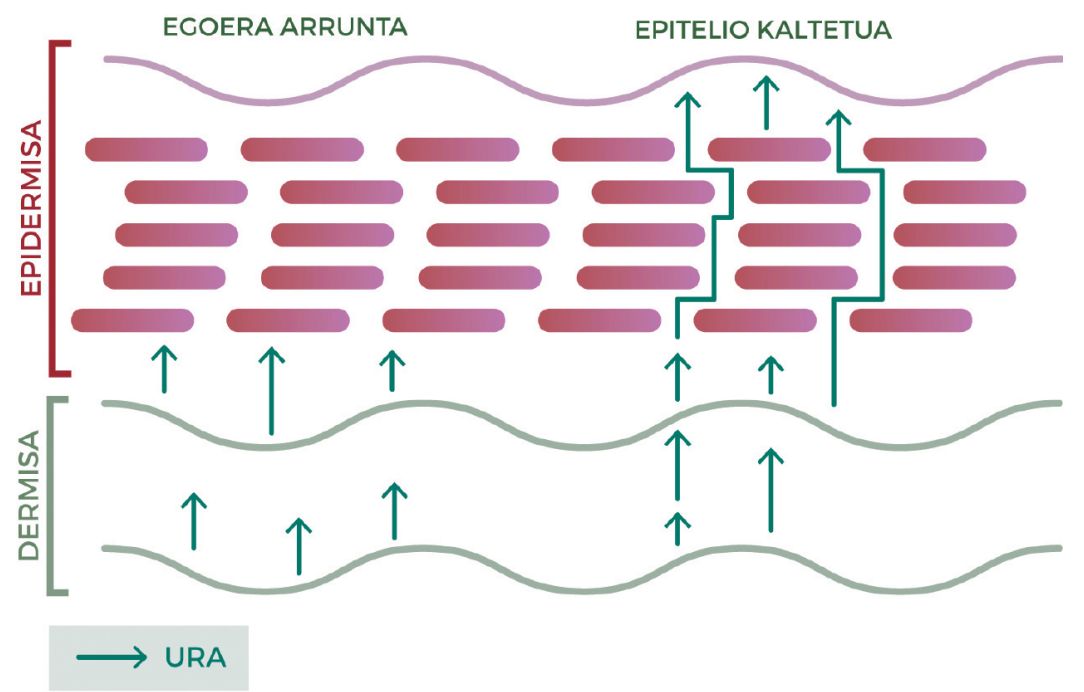

3. irudia. Egoera arruntean, geruza korneoaren barrera lipidikoak urtranspirazioa ekiditen du. Epitelioa kaltetuta dagoenean, aldiz, barneko geruzetatik ur-galera ematen da. 
Miren Izaguirre, Edorta Santos-Vizcaíno, Aiala Salvador, Amaia Esquisabel, José Luis Pedraz, Rosa María Hernández, Manoli Igartua

zeramiden berehalako ordezkapena izatea da [18]. AGEek, beste propietateez aparte, estratu korneoan funtzio bikoitza dute: alde batetik, barrera lipidikoaren egituraren berreskurapenean laguntzen dute ur-galera oztopatuz eta, beste aldetik, mintz zelularren erregenerazioan parte hartzen dute [19].

Badira landare jatorriko konposatu batzuk fitozeramida kantitate altuak dituztenak, hala nola jojoba-olioa (\% 96), kartamo-olioa (\% 78), mahatshazien olioa (\% 73) edo ekilore-olioa (\% 68), adibidez. AGE proportzio handiko landare-jatorriko olioak dira onagra-olioa, ekilore-olioa, lino-olioa, mosketa-arrosaren olioa edo gari-germenaren olioa.

Bensignor eta Bordeau-k (2005) txakurrekin egindako entsegu aurrekliniko batean, AGEekin formulatutako produktu baten hidratazio-gaitasuna frogatu zuten teknika korneometrikoaz baliaturik. Metodo horrek geruza korneoaren konstante dielektrikoaren bariazioa neurtzen du, izan ere, ia bere osotasunean uraren proportzioan oinarritzen baita.

Hidratazioaren handipen esanguratsu bat behatu zen lehenengo aplikaziotik 4. irudian ikusten den bezala. Hidratazioa mantendu zen lehenengo ordua igaro arte eta, ondoren, progresiboki murriztu. Hala ere, astebete igaro ondoren, hidratazio maila 2,5 aldiz handiagoa mantendu zen hasierako egoerarekin konparatuta (4. irudia) [19].

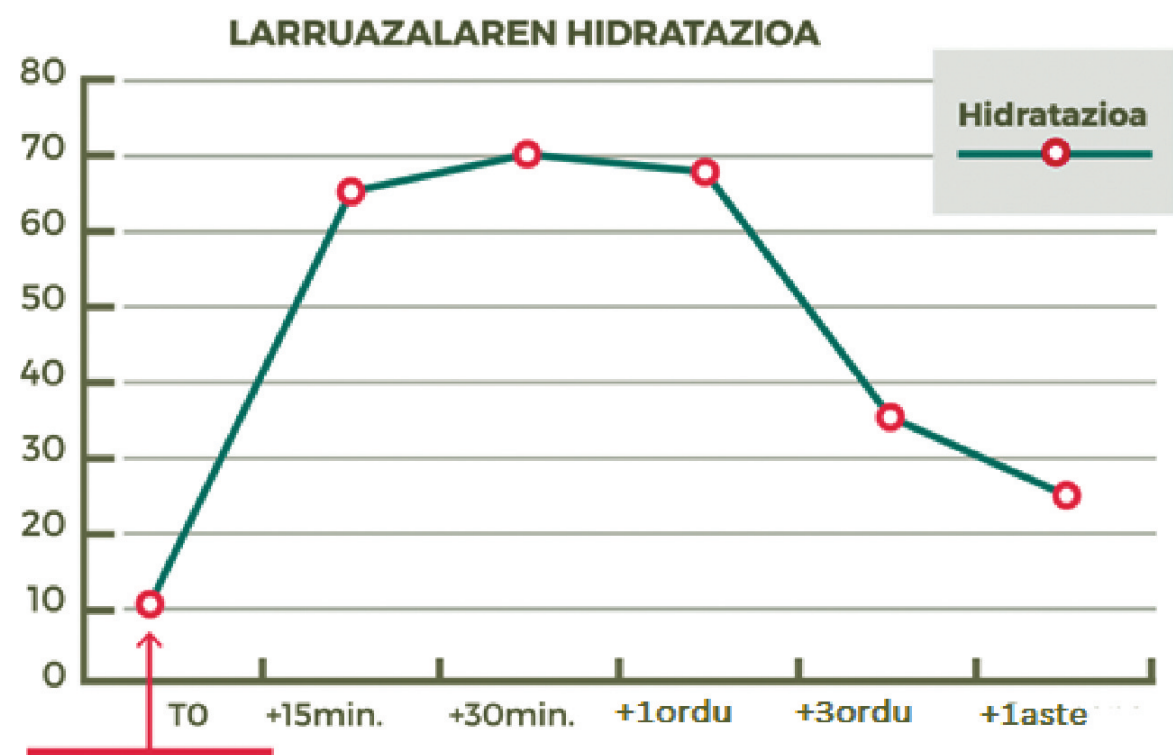

APLIKAZIOA

4. irudia. Larruazalaren hidratazioaren neurketa teknika korneometrikoaz. Baimenarekin erreproduzituta eta moldatuta [19]. 
KOSMETIKA ONKOLOGIKOA: kimioterapiak eta erradioterapiak larruazalean eragindako efektu desira-gaitzak eta horiek tratatzeko konposatu naturaletan oinarritutako formulazio berriak

\subsection{Antiinflamatorio, analgesiko eta antioxidatzaile naturalak}

Landareek badituzte aktibitate antiinflamatorioa eta antioxidatzailea duten metabolito sekundarioak: fenolak, flabonoideak eta fitoesterolak.

Fenol sinpleek hantura-prozesuaren bitartekari garrantzitsuen sintesia murrizten dute. Era berean, oxido nitrikoaren formazioa oztopatzen dute edema egoera hobetuz eta propietate antioxidatzaileak dituzte, oxigeno espezie erreaktiboen (OEE) murrizketan lagunduz. Fenol batzuek, gainera, efektu analgesikoa izan dezakete prostaglandinen sintesia inhibitu baitezakete.

Flabonoideek ere hantura-prozesuan parte hartzen duten entzima eta bitartekarien inhibitzaileak dira eta OEEn gehitzea murrizten dute. Sendabelarretan aurkitutako flabonoide ohikoenak apigenina (kamamilan eta elorri zurian, adibidez), luteolina (ezkai- edo oliba-olioan, adibidez) edo kerzetina (Ginkgo biloba espeziean, adibidez) dira. Era berean, flabonoideek ere aktibitate analgesikoa erakusten dute azido arakidonikoaren metabolismoa inhibituz.

Fitosterolek propietate antioxidatzaileak dituzte eta kortikosteroideen sintesia handitu eta degradazioa murrizten dute, hantura-egoera hobetuz. Gainera, aurrekoek bezala, efektu analgesikoa erakusten dute [20].

\subsection{Antimikrobiano naturalak}

Azken urteetan egindako ikerketek olio esentzialen propietate antibiotikoa aipatzen dute. Olio esentzialak landareetatik eta hainbat fruituren perikarpio gordinetik lortutako produktu natural usaintsuak dira. Beren eragin farmakologikoetako bat funtzio antimikrobianoa da. Olio esentzialak mikroorganismoaren pareta zelularraren egitura lipidikoa eraldatzeko eta zeharkatzeko gai dira, mintz plasmatikoaren osotasuna galaraziz. Modu horretan, mintzaren iragazkortasuna handitzen da, zelularen suntsipena eragingo duena.

Beren efektu antimikrobianoarengatik produktuetan gehien erabili izan diren olio esentzialak erromero-lorearen olioa (Rosmarinus officinalis), salbia sendakariaren olioa(Salvia officinalis), ezkai-lorearen olioa (Thymus vulgaris), te-zuhaitzaren olioa (Melaleuca alternifolia) eta eukalipto-olioa (Eucalyptus globulus) dira, besteak beste [21].

\subsection{Orbaintzaile eta erregeneratzaile zelular naturalak}

Landare-jatorria duten konposatuak medikuntza tradizionalean betidanik erabili izan dira horien orbaintze-eta erregenerazio-propietateengatik. Egungo formulazioetan gehienbat erabiltzen direnak hurrengoak dira: 
Miren Izaguirre, Edorta Santos-Vizcaíno, Aiala Salvador, Amaia Esquisabel, José Luis Pedraz, Rosa María Hernández, Manoli Igartua

Aloe vera $(A V)$ zaurien orbaintze-prozesuan laguntzen duen landarerik ezagunena da. Propietate horren erantzulea glukomananoa da: glukomananoak fibroblastoen hazkuntza-faktoreak estimulatzen ditu eta zelula horien aktibitatea eta proliferazioa bultzatzen ditu, kolagenoaren sintesia eta jariaketa handiagotuz. Entsegu aurrekliniko baten saguei eragindako ebakidura baten errepitelizazioa frogatu zen $A V$ gela hormona tiroideoen kremarekin eta sulfadiazina zilardun kremarekin konparatuz. $A V$ gelak emaitza hobeak erakutsi zituen fibroblastoen proliferazio-, angiogenesi-, errepitelizazio- eta zauriaren itxiera-prozesuetan. Horren arrazoietako bat $A V \mathrm{k}$ larruazalean infiltratzeko gaitasunarekin erlazionatuta egongo litzateke [22].

Calendula officinalis edo hilerri-lilia ere larruazalaren tratamenduetan landarerik erabilienetarikoa da, batez ere orbaintzaile eta antiinflamatorio gisa. In vivo egindako ikerketek frogatzen dute $C$. officinalisek orbaintzeeta errepitelizazio-denbora azkartzen dutela [23]

Centella asiatica landarearen estraktua zaurien orbaintze eraginkorra da. Orbaintze-prozesuaren erantzuleak bere konposatu triterpenikoak dira. Horiek orbainaren heltzea sustatzen dute I motako kolageno-sintesia estimulatuz, inflamazio-erreakzioa arinduz eta miofibroblastoen produkzioa bultzatuz. Bere ekintza in vivo eta in vitro egindako esperimentuetan egiaztatu da [24].

Rosa eglanteria edo mosketa-arrosaren olioa arrosa-espezie horren hazietatik erauzten den olio esentziala da. Olio horren konposizio kimikoa AGE poliinsaturatuen ehuneko handiagatik bereizten da prozesu askotan parte hartzen dute: prostaglandinen sintesian, mintzaren erregenerazioan, defentsa-mekanismoetan eta erregenerazio zelularrarekin erlazionaturiko prozesu biologikoetan, adibidez. Hori dela eta, arrosamosketaren olioa epitelizazioa estimulatzeko produktu askotan erabili izan da. Bere epitelizazio-gaitasuna frogatzeko egindako entsegu kliniko baten, mastektomia izandako 45-68 urteko 10 emakumek parte hartu zuten. Puntuak kendu ostean, 3 orbainetan arrosa-mosketaren olioa jarri zitzaien egunean bitan 3 hilabetez. Denbora hori igaro ondoren, orbainen hobekuntza nabaria behatu izan zen, handiagotze kutaneoak ez zirela gertatu eta larruazalaren elastikotasunak eta koloreak hobera egin zutela [25].

\section{LABORATEGI KOSMETIKO ETA DERMATOLOGIKOAK}

Azken urteetan laborategi dermatologiko eta kosmetikoek haien produktu-gamak handiagotu dituzte tratamendu onkologikoen ondorioz larruazal kaltetua zaindu eta erreparatzeko estraktu naturaletan oinarritutako produktuekin. 
KOSMETIKA ONKOLOGIKOA: kimioterapiak eta erradioterapiak larruazalean eragindako efektu desira-gaitzak eta horiek tratatzeko konposatu naturaletan oinarritutako formulazio berriak

\subsection{María D’uol. Laborategi kosmetikoa}

Gasteizen ezarritako laborategi honek 2015eko urrian Cosmética Onco lerroa merkaturatu zuen, landare ezberdinen estraktuetan oinarritutako produktuez osatutakoa:

- Lozio erreparatzailea: ebakuntza osteko orbaina, epitelio kaltetua eta kimioterapiagatik orbaintze-fasean dagoen aknea tratatzeko produktua. Centella asiaticaren estraktuaz formulatutako lozioa da.

- Olio erreparatzailea: produktu hau zauri edo ultzerak ageri diren kasuak tratatzeko erabiltzen da. Bere oinarrizko osagaiak mahats-hazien olioa eta ekilore-olioa AGE iturri gisa dira, kamamila hantura kontrako osagai bezala eta antibakteriano gisa eukalipto-olio esentziala gehituta.

- Baltsamo erreparatzailea: narritatutako azala arintzea helburu duen produktua. Bere osagaien artean ditugu karite-gurina konposatu lasaigarria eta AGE iturritzat, mahats-hazien olioa duen AGE proportzio handiagatik, $A V$, mosketa-arrosaren olioa, eta alantoina erregeneratzaile moduaneta eguzki-filtroak.

- Beauty cream: narritadura, pruritoa, gorritasuna eta hantura arintzeko produktua. Bere formulazioan Phragmites kharka eta Poria coco landareak erabiltzen dira, medikuntza tradizionalean aktibitate immunologikoa handitzeko eta hantura kontrako propietateak dituelako erabiltzen da. Bere formulazioan ere karite-guruina, mahats-hazien olioa eta kartamo-olioa ditugu AGE iturritzat, eta laktosa eta esnearen proteina, biologikoki aktiboak diren polipeptidoek larruazalaren barrera lipidikoaren erregenerazioan parte hartzen dutenak (1. taula) [26].

1. taula. Cosmética Onco lerroa osatzen duten produktuen konposaketa.

\begin{tabular}{|c|c|c|c|}
\hline $\begin{array}{c}\text { Lozio } \\
\text { erreparatzailea }\end{array}$ & $\begin{array}{c}\text { Olio } \\
\text { erreparatzailea }\end{array}$ & Baltsamo erreparatzailea & Beauty cream \\
\hline Centella asiática & $\begin{array}{l}\text { Mahats-hazien olioa } \\
\text { Ekilore-olioa } \\
\text { Kamamila-olioa } \\
\text { Eukalipto-olioa }\end{array}$ & $\begin{array}{l}\text { Karite-gurina } \\
\text { Mahats-hazien olioa } \\
\text { AV } \\
\text { Mosketa-arrosaren olioa } \\
\text { Alantoina } \\
\text { Eguzki-filtroak }\end{array}$ & $\begin{array}{l}\text { Phargmites kharka } \\
\text { Poria coco } \\
\text { Karite-gurina } \\
\text { Mahats-hazien olioa } \\
\text { Kartamo-olioa } \\
\text { Laktosa eta esnearen proteina }\end{array}$ \\
\hline
\end{tabular}


Miren Izaguirre, Edorta Santos-Vizcaíno, Aiala Salvador, Amaia Esquisabel, José Luis Pedraz, Rosa María Hernández, Manoli Igartua

\subsection{INOXDERM}

INOXDERM laborategiek OnCosmetics kosmetika-lerroa sortu zuten tratamendu onkologikoa jasotzen ari diren edo jaso duten pertsonei zuzenduta. Produktu horiek landare ezberdinen estraktuez, era berean, parabeno, parafina, perfume eta alkoholik gabe formulatutakoak dira. Enpresa dermokosmetiko horrek, landare estraktuez aparte, bere laborategian sintetizatutako lasaigarri efektua duen hexapeptidoa erabiltzen du. Horrek ehunen erregenerazioan parte hartzen du eta pruritoa arintzeko gaitasuna du. Lerro hori osatzen duten produktuak hauek dira:

- Olio bizia: zonalde bereziki lehor eta ezkatatuetan aplikatzeko produktua da. Almendra-olioa (AGE eta bitamina antioxidatzaile kantitate altukoa), masusta gorriaren olio antioxidatzailea, hiperiko-olioa (AGE kantitate altukoa), eta gantz-azido polioxigenatuak, erregenerazio-prozesua azkartzeko gaitasuna dutenak.

- Gaueko krema: hidratatzaile moduan glizerina, betaina eta Aloe vera; erregenerazio-propietateengatik gantz-azido polioxigenatuak, alantoina, mosketa-arrosaren olioa eta $A V$; ekintza lasaigarriagatik intsentsu-olioa, eta lasaigarri efektua duen hexapeptidoa; eta nutrizio-iturri moduan karite- eta mango-gurina.

2. taula. OnCosmetics lerroa osatzen duten produktuen konposaketa.

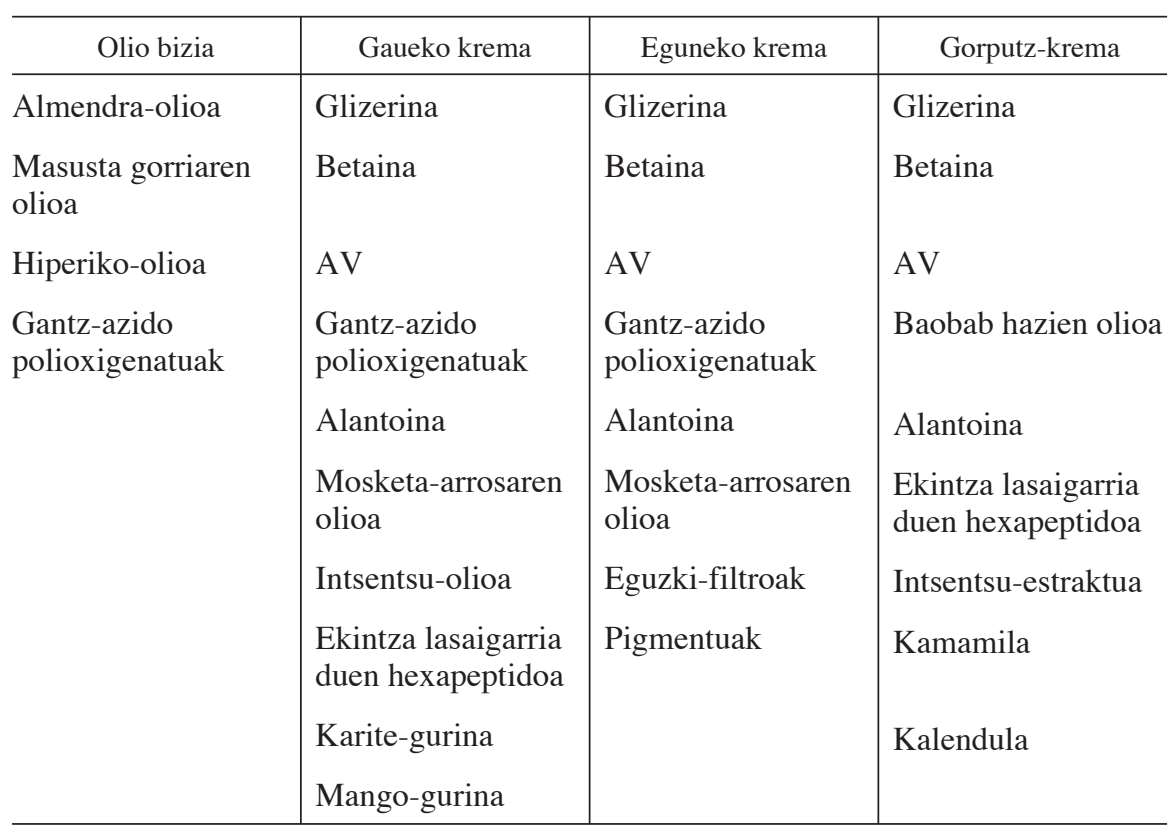


KOSMETIKA ONKOLOGIKOA: kimioterapiak eta erradioterapiak larruazalean eragindako efektu desira-gaitzak eta horiek tratatzeko konposatu naturaletan oinarritutako formulazio berriak

- Eguneko krema: gaueko kremaren formulazio bera dauka, baina honi eguzki-filtroak gehitzen zaizkio, UV izpietatik babestuta egoteko, eta baita pigmentuak ere, kaltetutako azalaren kolorea hobetu eta hiperpigmentazioak disimulatzeko.

- Gorputz-krema: konposatu hidratatzaile moduan glizerina, betaina eta $A V$; haien erregenerazio-efektuagatik gantz-azido polioxigenatuak, Baobab hazien olioa (bitamina eta AGE kantitate altuak) eta alantoina; eta ekintza lasaigarriagatik hexapeptido lasaigarria, intsentsu-estraktua, kamamila- eta kalendula-estraktuak (2. taula) [27].

\subsection{BEACON Biomedicine}

BEACON Biomedicine Madrilen kokatutako enpresa bioteknologikoak fabrikatutako TECTUM Skincare lerroa erradioterapia eta kimioterapia jasotzen duten pazienteen larruazala tratatzeko diseinatuta dago.

Produktu horien berezitasuna, estraktu begetalak erabiltzeaz gain, $\beta$-Hazkuntza Faktore eraldatzaile edo TGF- $\beta$ eta TECTUM SKINCARE izeneko molekula peptidiko baten erabilera da. Estraktu begetalen bidez, ehunen birsorkuntzarako beharrezkoak diren nutrienteak ematen dizkio larruazalari eta TGF- $\beta$ ren erabilerari esker erregenerazioa sustatzen da. Laborategi horietan aurkitutako TECTUM SKINCARE (Tectum 11 edo Tc11) molekulak funtzio bikoitza du: alde batetik, tratamendu onkologikoa hasi aurretik larruazalak jasoko duen erasoetatik babesten du eta, beste aldetik, hipersentikortasun-erreakzio berantiarrak kontrolatzen ditu. Molekula horrek gizakiok berez dugun ATM proteina (Ataxia-telangiectasia mutated protein) aktibatzen du, bere funtzioa DNA katean ematen diren kalteak detektatzea izanik. DNAren kaltea oso handia denean, apoptosira eramango du zelula; kaltea txikia denean, ordea, DNA erreparatzeko seinalizazio-bideak aktibatuko ditu.

Lerro horretan hainbat produktu aurkitzen ditugu:

- Pregorputz-krema: produktu honen helburua tratamendu onkologikoak eragiten dituen erasoetarako larruazalaren prestaketa da. Larruazala prestatzeko, Tc11-ren qr forma erabiliko da: molekula horrek ATM proteinak erasoen aurrean aktibo egotea baimenduko du. Tc11 forma hori degradazio azkarrekoa da, 4-6 orduz behin aplikatu beharrekoa. Produktu horren osagai aktiboak dira Tc11 molekularen qr 150 unitate aktibo, TGF- $\beta$ ren 100 unitate aktibo, oliba-olioa, glizerina begetala hezegarri gisa, kontserbagarri naturala, alantoina, mosketa-arrosaren olioa eta E bitamina dira.

- Gorputz-krema: tratamendu onkologikoen ondorioz sentsibilizatutako larruazalak erreparatzeko formulatua. Produktu honetan pregorputz-kremarekin alderatuta, Tc11-ren sr formaren erabilera al- 
Miren Izaguirre, Edorta Santos-Vizcaíno, Aiala Salvador, Amaia Esquisabel, José Luis Pedraz, Rosa María Hernández, Manoli Igartua

datzen da. Horrek, Tc11qr-rekin konparatuta, degradazio motelagoa izango du eta denbora luzeagoz larruazalean mantentzea baimenduko du.

- Esku-krema: eritema akrala tratatzeko formulatutako produktua da. Tc11sr-en 150 unitate aktibo, TGF- $\beta$ ren 100 unitate aktibo, olibaolioa, glizerina begetala, kontserbagarri naturala, alantoina, mosketa-arrosaren olioa eta E bitamina daramatza. Gainera, kamamilaolioa gehitzen zaio, bere konposatu den bisabolol molekulak dituen propietate antiinflamatzaile eta lasaitzaileengatik (3. taula).

Perfume, alkohol eta tentsioaktiborik gabe formulatuak dira produktu guztiak [28].

3. taula. TECTUM SKINCARE lerroa osatzen duten produktuen konposaketa.

\begin{tabular}{l|l|l}
\hline \multicolumn{1}{c|}{ Pregorputz-krema } & \multicolumn{1}{c|}{ Gorputz-krema } & \multicolumn{1}{c}{ Esku-krema } \\
\hline Tc11qr, 150 unitate aktibo & Tc11sr, 150 unitate aktibo & Tc11sr, 150 unitate aktibo \\
TGF- $\beta, 100$ unitate aktibo & TGF- $\beta, 100$ unitate aktibo & TGF- $\beta, 100$ unitate aktibo \\
Oliba-olioa & Oliba-olioa & Oliba-olioa \\
Glizerina & Glizerina & Glizerina \\
Kontserbagarri naturala & Kontserbagarri naturala & Kontserbagarri naturala \\
Alantoina & Alantoina & Alantoina \\
Mosketa-arrosaren olioa & Mosketa-arrosaren olioa & Mosketa-arrosaren olioa \\
E bitamina & E bitamina & E bitamina \\
& & Kamamila \\
\hline
\end{tabular}

\subsection{IFC}

IFC laborategiek eratutako Endocare lerroaren barruan, Radiocare krema larruazal onkologikoa erreparatzeko diseinaturik dago. Produktu horrek ez ditu landare estraktuak osagai aktibo gisa erabiltzen, baizik eta Cryptomphalus aspersa barraskilotik lortutako jariakina. Eskrezio glikoproteiko horrek berriztapen kutaneoa sustatzen du hainbat mekanismoren bitartez: aktibitate antioxidatzailea du erradikal libreen sorrera inhibituz, fibroblastoen proliferazio sustatzailea da eta kolagenasa aktibitatea du kolageno zaharkitua deuseztatuz eta kolageno matrize estrazelularraren sintesi egokia faboratuz [29]. 
KOSMETIKA ONKOLOGIKOA: kimioterapiak eta erradioterapiak larruazalean eragindako efektu desira-gaitzak eta horiek tratatzeko konposatu naturaletan oinarritutako formulazio berriak

\section{AZKEN GOGOETA ETA ETORKIZUNEKO PERSPEKTIBAK}

OMSk aurreikusten du hurrengo bi hamarkadetan minbizi-kasu berrien agerpenak \% 70 egingo duela gora mundu mailan, hau da, 2030erako beste 22 milioi minbizi-kasu izango ditugula. Minbiziaren tratamenduan, azken urteetan egindako aurrerapenengatik, pazienteen bizi-itxaropena asko handitu da, baina baita tratamendu onkologikoen ondorioz sortutako efektu desiragaitzen agerpena ere, larruazalean ematen direnak, adibidez [30].

Medikuntza tradizionalaren erabilera munduko eskualde desberdinetan arrunta da, hala nola Afrika, Asia eta Latinoamerikan, osasun-zerbitzuetara heltzeko zailtasunak dituzten populazioetan hain zuzen ere. Kalkulatzen da Asia eta Afrika populazioaren \% 80 baino gehiagok medikuntza tradizionaleko terapiak osasun-zerbitzu primariotzat erabiltzen dituztela eta Txinan osasun-zerbitzu totalaren \% 40 terapia horietan oinarriturik dagoela. Herrialde garatuetan ere medikuntza tradizionala erabiltzeko joera handitzen ari da: Kanadako populazioaren \% 70ek terapia tradizionalak erabiltzen ditu, Ameriketako Estatu Batuetan \% 42k, Frantzian \% 75ek, Australian $\%$ 69k eta Zelanda Berrian \% 30ek.

Azken urteetan erauzketa-prozeduretan, purifikazio-metodoetan, prozedura metodologikoan eta tratamendu klinikoetan egindako berrikuntzei esker, terapia tradizionalen nolakotasuna, efikazia eta segurtasuna handitzea lortu da. Hala ere, terapia horien erabilera mendeetan zehar jasotako esperientzian eta jakiturian oinarritzen da, ebidentzia zientifikoetan izan beharrean.

Dena dela, azken urteetan hainbat laborategik medikuntza tradizionalean erabilitako konposatuen ezagutzan zentratu dira, horien ekintza-mekanismoak eta aktibitate biologikoak ezagutzeko helburuarekin [23].

Hortaz, minbizi-kasu berrien kopurua handituko dela aurreikusi denez eta medikuntza tradizionala erabiltzeko joera handitu denez azken urteetan, pentsa daiteke produktu horien erabilera handiagotuko dela paziente onkologikoen bizitza-kalitatea hobetzeko.

\section{BIBLIOGRAFIA}

[1] PUENTE J. eta DE VELASCO G. 2016. «¿Qué es el cáncer y cómo se desarrolla?». SEOM. Eskuragarri: http://www.seom.org/en/informacion-sobre-elcancer/que-es-el-cancer-y-como-se-desarrolla [2017/03/6].

[2] «¿Qué es el cáncer?». Instituto Nacional de Cáncer. Eskuragarri: http:// www.cancer.gov/espanol/cancer/que-es [2017/5/9].

[3] «¿Cómo se trata el cáncer de mama?». Clínica Universidad de Navarra. Eskuragarri: http://www.cun.es/enfermedades-tratamientos/enfermedades/ cancer-mama/tratamiento/como-se-trata [2017/5/9]. 
Miren Izaguirre, Edorta Santos-Vizcaíno, Aiala Salvador, Amaia Esquisabel, José Luis Pedraz, Rosa María Hernández, Manoli Igartua

[4] MONTERO A., HERVAS A., MORERA R., SANCHO S., CORDOBA S., CORONA J.A. et al. 2005. «Control de síntomas crónicos. Efectos secundarios del tratamiento con radioterapia y quimioterapia». Oncología, 28, 41-50.

[5] WBENSMITH, Creative Commons lizentziapean erreproduzituta.

[6] MERINO J. eta NORIEGA M.J. «La Piel: estructura y funciones». Fisiología general, 2-4.

[7] TAKEO M., LEE W. eta ITO M. 2015. «Wound healing and skin regeneration». Cold Spring Harbor Perspectives in Medicine, 5, 1-5.

[8] JAEN P., TRUCHUELO M.T., O. SANMARTIN eta SOTO J. 2015. «El cáncer y la piel». Guía de cuidados dermatológicos del paciente oncológico.

[9] «Problemas de la piel: cicatrices y heridas». American Cancer Society. Eskuragarri: https://www.cancer.org/es/tratamiento/tratamientos-y-efectossecundarios/efectos-secundarios-fisicos/problemas-de-la-piel/cicatrices-yheridas.html[2017/9/13].

[10] VILlanueVA T., AlCAlA D., VEGA M. eta PERALTA M.L. 2012. «Guía de práctica clínica para prevención y tratamiento de la radiodermitis aguda». Dermatol, 56, 3-13.

[11] BARCO D., PUIS L., VILARRASA E., LOPEZ-FERRER A. eta RUIZ V. 2009. «La piel del paciente oncológico. Atención especial». Farmacia Profesional, 23, 52-55.

[12] GONZALEZ A. eta BUEDO GARCIA J. 2008. «Cuidados de la piel irradiada». Formación Dermatológica, 5, 8-15.

[13] FARIÑA M.C., ANDRADE J., SORIANO M.L., GRILLI R., DOMINE M., MARTN L. et al. 1998. «Eritema acral inducido por quimioterapia. Descripción de cuatro casos y revisión de la literatura». Actas Dermo-Sifiliográficas, 89, 385-391.

[14] FARIÑA M.C. 2000.« Manifestaciones cutáneas en relación con la administración de quimioterapia. Estúdio clinicopatológico». Actas Dermo-Sifiliográficas, 91, 121-144.

[15] ALLEVATO M.A. 2008. «Efectos adversos cutáneos de la terapia antineoplásica».Actualizaciones Terapéuticas Dermatológicas y Estéticas, 31, 78-91.

[16] «Ureadin. Ultra 30. Crema emoliente». ISDIN. Eskuragarri: https:// www.isdin.com/es/productos/ureadin/crema-emoliente-piel-engrosada-ydurezas [2017/5/9]

[17] RUIZ A. «Mucositis. Epitelitis. Cuidados». VIII Jornadas Oncológicas Internacionales.

[18] UCLAF R.1994. «Composiciones cosméticas y dermatológicas que asocian ceramidas y ácido linoleico, y su preparación». Europar patentea 091.108.

[19] BESIGNOR E. eta BORDEAU W. 2005.«Utilisation d'un spot-on à base d'acide gras et d'huiles essentielles pour carnivores domestiques: étude ouverte ». Informations Dermatologiques Vétérinaires, 24-28.

[20] FERNANDEZ F. eta TORRES M. «Inflamación y plantas medicinales». Organización Panamericana de la Salud. 
KOSMETIKA ONKOLOGIKOA: kimioterapiak eta erradioterapiak larruazalean eragindako efektu desira-gaitzak eta horiek tratatzeko konposatu naturaletan oinarritutako formulazio berriak

[21] DOMINGO D. eta LOPEZ-BREA M. 2003. «Plantas con acción antimicrobiana». Revista Española de Quimioterapia, 16, 385-393.

[22] TARAMESHLOO M., NOROUZIAN M., ZAREIN-DOLAB S., DADPAY M., MOHSENIFAR J. eta GAZOR R. 2012. «Aloe vera gel and thyroid hormone cream may improve wound healing in Wistar rats». Anatomy \& Cell Biology, 45, 170.

[23] BARTOLO P. eta PEREIRA R. 2013. «Traditional Therapies for Skin Wound Healing». Advances in wound care, 5, 208-229.

[24] ALONSO M.J. 2009. «Centella asiática. Una planta con historia e interesantes propiedades». Ámbito farmacéutico, 28, 98-104.

[25]. ESPINOZA, T.; VALENCIA, E.; QUEVEDO, R. eta DIAZ, O. 2016. «Importancia y propiedades físico química de la Rosa mosqueta ( $R$. canina, R. rubiginosa): una revisión». Scientia Agropecuaria, 7, 67-78.

[26] UNCETA-BARRENECHEA M. «Cosmética Onco». María D’uol. Laboratorio de cosmética. Eskuragarri: http://www.cosmeticaonco.com/ [2017/5/9].

[27] OnCosmetics. Eskuragarri: http://oncosmetics.es/ [2017/5/9].

[28] «Cosmética Oncológica». BEACON Biomedicine. Eskuragarri: http:// beaconbio.com/cosmetica-oncologica/ [2017/5/9].

[29] «Radiocare». IFC. Eskuragarri: http://www.ifc-spain.com/endocare/ [2017/5/9].

[30] STEWART B. eta KLEIHUES P.2014. «World Cancer Report». World Health Organization. 